
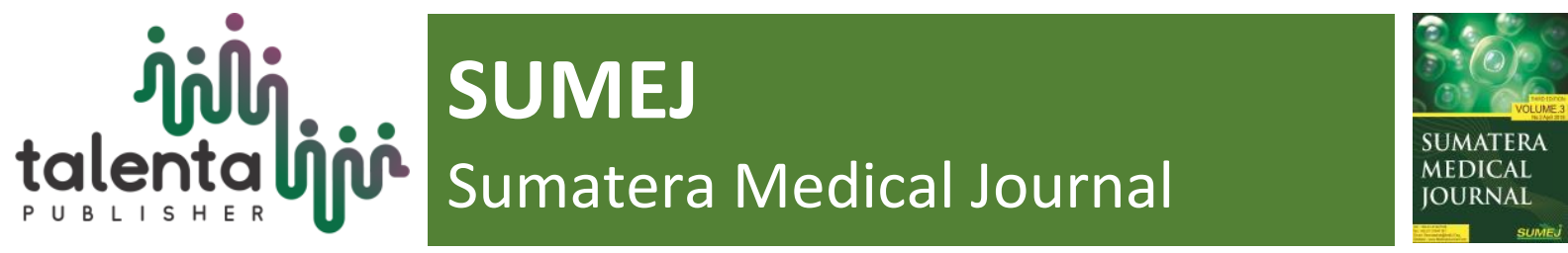

\title{
Timi Flow Between Streptokinase and Alteplase in Successful Fibrinolytic
}

\author{
Dika Ashrinda ${ }^{*}$, Refli Hasan', Cut Aryfa Andra ${ }^{3}, Z^{2}$ lfikri Muhtar ${ }^{4}$, Harris \\ Hasan $^{5}$
}

1,2,3,4,5 Department of Cardiology and Vascular Medicine, Faculty of Medicine Universitas Sumatera Utara, Indonesia

\begin{abstract}
Background: STEMI with onset $\leq 12$ hours, necessary to take Primary Percutaneous Coronary Intervention (pPCI), but if there is no facility, another therapy is fibrinolytic, to improve blood flow in the coronary artery and myocardial function, thus reducing infarction expansion. This is a retrospective study in STEMI patient's onset $\leq 12$ hours, had performed successful fibrinolytic with Streptokinase (SK) and Alteplase (tPA) from January 2015 to August 2017. TIMI flow was assessed by coronary angiography. There were 54 patients who had performed successful fibrinolytic therapy with SK and tPA; each group had 27 patients. In the SK group, there were nine patients $(33.3 \%)$ with TIMI flow 2 and 18 patients $(66.7 \%)$ with TIMI flow 3 . While in the tPA group there were 11 patients $(40.7 \%)$ with TIMI flow 2, 16 patients $(59.3 \%)$ with TIMI flow 3, $(\mathrm{p}=0.573)$. There is no difference in TIMI flow between SK and tPA on STEMI patients after success fibrinolytic therapy.
\end{abstract}

Keywords: STEMI, Fibrinolytic, Streptokinase, Alteplase, TIMI Flow

\begin{abstract}
Abstrak. STEMI dengan onset $\leq 12$ jam, diperlukan untuk mengambil Intervensi Koroner Perkutan Primer (pPCI), tetapi jika tidak ada fasilitas, terapi lain adalah fibrinolitik, untuk meningkatkan aliran darah di arteri koroner dan fungsi miokardial, sehingga mengurangi ekspansi infark. Ini adalah penelitian retrospektif pada pasien STEMI onset $\leq 12$ jam, telah berhasil fibrinolytic dengan Streptokinase (SK) dan Alteplase (tPA) dari Januari 2015 hingga Agustus 2017. Aliran TIMI dinilai oleh angiografi koroner. Ada 54 pasien yang telah melakukan terapi fibrinolitik yang sukses dengan SK dan tPA; setiap kelompok memiliki 27 pasien. Dalam kelompok SK, ada sembilan pasien (33,3\%) dengan aliran TIMI 2 dan 18 pasien (66,7\%) dengan aliran TIMI 3. Sementara pada kelompok tPA ada 11 pasien $(40,7 \%)$ dengan aliran TIMI 2, 16 pasien (59,3\%) dengan aliran TIMI 3, ( $p=0,573)$. Tidak ada perbedaan dalam aliran TIMI antara SK dan tPA pada pasien STEMI setelah terapi fibrinolitik sukses.
\end{abstract}

Kata kunci: STEMI, Fibrinolytic, Streptokinase, Alteplase, TIMI Flow

Received 2 January 2019 | Revised 16 January 2019 | Accepted 31 January 2019

${ }^{*}$ Corresponding author at: Faculty of Medicine, Universitas Sumatera Utara, Medan, Indonesia 


\section{Introduction}

Fibrinolytic therapy is used to improve blood flow in the coronary due to occlusion caused by thrombus, thereby reducing infarction expansion, improving myocardial function in the patient with STEMI [1]. De Lemoss et al. (2001), compared the angiographic reperfusion assessment with the ST segment resolution assessment on the administration of SK with tPA. Both fibrinolytic agents have more ST-segment resolution correlations and a higher average IRA patency with TIMI flow 3. However, tPA has a better TIMI flow compared to SK [2]. The aim of this study was to assess and compare TIMI flow between fibrinolytic agents SK and tPA after successful fibrinolytic.

\section{Methodology}

We examined data from medical records of patients who treated at Haji Adam Malik General Hospital from January 2015 to July 2017. Samples were patients who had been diagnosed with STEMI onset $\leq 12$ hours, which had successfully performed fibrinolytic therapy with SK or tPA, and given the same dual antiplatelet (Aspilet $160 \mathrm{mg}$ and Clopidogrel $300 \mathrm{mg}$ ) before performed fibrinolytic therapy, then followed by five days of Enoxaparin. We examined early ECG recording and 90 minutes after fibrinolytic, laboratory examination, coronary angiography record.

Succeed fibrinolytic is a decreased ST segment $\geq 50 \%$, at least two paired leads, compare early ECG and 90-minute ECG after fibrinolytic. Then the whole sample is divided into two groups, first group with SK, and the second group with tPA. Assessment of TIMI flow was performed by two interventions cardiologist through a coronary angiography recording.

The data are presented descriptively with frequency distribution and percentage for categorical data. While numerical data is presented with mean and Standard Deviation (SD) values for normally distributed data, while abnormally distributed data with the median. The normality test of numerical variables in all subjects will use Kolmogorov Smirnov ( $\mathrm{n}>50)$. Both categorical variables will be tested the correlation, whether there is a significant correlation. Analysis of statistical data using SPSS software version 20 , p-value $<0.05$ is statistically significant.

\section{Results}

Total samples were 54 patients, and each group had 27 samples. The mean age was 53 years for the SK group and 56 years in the tPA group. Males were the largest sample, 48 patients (88.9\%), which 25 patients (92.6\%) in the SK group and 23 patients (85.2\%) in the tPA group. Total risk factor for CHD was highest in age and smoking was 43 patients. 
This study divided STEMI into two groups, anterior and Inferior STEMI. In the SK group, inferior STEMI compared to the anterior STEMI, 15 patients (55.6\%) and 12 patients (44.4\%). In the tPA group, Anterior STEMI was more that 19 patients (70.4\%), compared with Inferior STEMI 8 patients $(29.6 \%)$. The onset of chest pain divided into four groups. The onset of chest pain was greater in the > 3-6 hour's group, 25 patients $(46.3 \%)$, of which 11 patients $(40.7 \%)$ in the SK group and 14 patients (51.9\%) in the tPA group. The second onset of chest pain group was 0-3 hours, 21 patients (38.9\%), 12 patients in the SK group (44.4\%) while in the tPA group of 9 patients $(33.3 \%)$ (Table 1).

In the laboratory characteristics were found statistically significant differences between the SK and TPA groups, there are MPV and cardiac enzymes (Troponin and CKMB). On the MPV assessment in the SK group, an average value was $9.56 \mathrm{fL}$, whereas in the tPA group was $9.99 \mathrm{fL}$ ( $p$ value $=0.044)$. In the cardiac enzyme group with $p$-value $=0.000$, which Troponin values were divided into two groups (+) and (-). 24 patients (44.4\%) with positive troponin, which five patients (5\%) in the SK group and 19 patients $(70.4 \%)$ in the tPA group. The CKMB cardiac enzyme examination in this study was also significant with $\mathrm{p}$-value $=0.003$, whereas the median of the SK group was 35 units / L, while in the tPA group was 62 units / L (Table 1).

Twenty patients (37\%) with TIMI flow 2, while 34 patients (63\%) with TIMI flow 3. In the SK group, TIMI flow two there were nine patients (33.3\%), and TIMI flow 3 is 18 patients (66.7\%), while in the tPA group, 11 patients (40.7\%) with TIMI flow 2 and 16 patients (59.3\%) with TIMI flow 3. The TIMI flow ratio between SK and tPA was not was statistically significant with pvalue $=0,573$ (table 2). The TIMI flow assessment was observed with two interventionists. The value of Kappa $(\kappa)$ inter-observer variability is 0.623 (p-value $=0.000$ ).

Table 1 Baseline Characteristics

\begin{tabular}{|c|c|c|c|}
\hline \multirow[b]{2}{*}{ Characteristics } & \multicolumn{2}{|c|}{ Fibrinolytic } & \multirow[b]{2}{*}{$P$ Value } \\
\hline & $\begin{array}{l}\text { SK } \\
(n=27)\end{array}$ & $\begin{array}{l}\text { tPA } \\
(\mathrm{n}=27)\end{array}$ & \\
\hline $\begin{array}{l}\text { Age }(\text { mean } \pm S D) \text {, } \\
\text { years }\end{array}$ & $53 \pm 8$ & $56 \pm 8$ & $0,197^{*}$ \\
\hline Male & $25(92,6)$ & $23(85,2)$ & $0.334^{\mathrm{b}}$ \\
\hline \multicolumn{4}{|l|}{$\begin{array}{l}\text { CHD Risk Factors } \\
(\mathrm{n}, \%)\end{array}$} \\
\hline Age & $20(74,1)$ & $23(85,2)$ & $0,311^{\mathrm{a}}$ \\
\hline Type 2 DM & $9(33,3)$ & $11(40,7)$ & $0,573^{\mathrm{a}}$ \\
\hline Hypertension & $9(33,3)$ & $12(44,4)$ & $0,420^{\mathrm{a}}$ \\
\hline Smoking & $23(85,2)$ & $20(74,1)$ & $0,311^{\mathrm{a}}$ \\
\hline Family History & $1(3,7)$ & - & $0,500^{\mathrm{b}}$ \\
\hline $\begin{array}{l}\text { Dislipidemia } \\
\text { STEMI (n, \%) }\end{array}$ & $11(40,7)$ & $13(48,1)$ & $0,584^{\mathrm{a}}$ \\
\hline Anterior & $12(44,4)$ & $19(70,4)$ & $0,054^{\mathrm{a}}$ \\
\hline Inferior & $15(55,6)$ & $8(29,6)$ & \\
\hline Onset of paint (h) & $4(0,5-8)$ & $\begin{array}{l}4(1- \\
11,5)\end{array}$ & $0,536^{\#}$ \\
\hline $\begin{array}{l}\text { Onset of chest } \\
\text { pain }(n, \%)\end{array}$ & & & $0,460^{\mathrm{c}}$ \\
\hline
\end{tabular}




\begin{tabular}{|c|c|c|c|}
\hline $0-3 \mathrm{~h}$ & $12(44,4)$ & $9(33,3)$ & \\
\hline$>3-6 h$ & $11(40,7)$ & $14(51,9)$ & \\
\hline$>6-9 h$ & $4(14,8)$ & $2(7,4)$ & \\
\hline$>9-12 \mathrm{~h}$ & - & $2(7,4)$ & \\
\hline Killip (n, \%) & & & \\
\hline I & $25(92,6)$ & $22(81,5)$ & \multirow{2}{*}{$0.210^{\mathrm{b}}$} \\
\hline II & $2(7,4)$ & $5(18,5)$ & \\
\hline Hemoglobin, g/dL & $\begin{array}{l}14,70 \pm 1, \\
71\end{array}$ & $\begin{array}{l}14,73 \pm 1 \\
46\end{array}$ & $0,952 *$ \\
\hline Hematocrit, \% & $\begin{array}{l}42,33 \pm 4 \\
42\end{array}$ & $\begin{array}{l}42,71 \pm 5 \\
19\end{array}$ & $0,772 *$ \\
\hline Leukocyte, $/ \mu \mathrm{L}$ & $\begin{array}{l}12.3 \mathrm{k} \pm 3 . \\
2 \mathrm{k}\end{array}$ & $\begin{array}{l}12.3 \mathrm{k} \pm 3 . \\
2 \mathrm{k}\end{array}$ & $0,980 *$ \\
\hline Platelet, / $\mu \mathrm{L}$ & $\begin{array}{l}255 \mathrm{k} \pm 46 \\
\mathrm{k}\end{array}$ & $\begin{array}{l}265 \mathrm{k} \pm 54 \\
\mathrm{k}\end{array}$ & $0,514^{*}$ \\
\hline MPV, fL & $\begin{array}{l}9,56 \pm 0,8 \\
7\end{array}$ & $\begin{array}{l}9,99 \pm 0,6 \\
7\end{array}$ & $0.044 *$ \\
\hline PDW, \% & $\begin{array}{l}10.95 \pm 1 \\
65\end{array}$ & $\begin{array}{l}11,23 \pm 1 \\
43\end{array}$ & $0,512 *$ \\
\hline $\begin{array}{l}\text { Troponin }(\mathrm{n}, \%) \\
(+)\end{array}$ & $5(18,5)$ & $19(70,4)$ & $0,000^{*}$ \\
\hline$(-)$ & $22(81,5)$ & $8(29,6)$ & \\
\hline CKMB, unit/L & $\begin{array}{l}35 \\
(11-211)\end{array}$ & $\begin{array}{l}62 \\
(21-327)\end{array}$ & $0.003^{\#}$ \\
\hline
\end{tabular}

n: total samples; SK: Streptokinase; tPA: Alteplase; ${ }^{*}$ Student $t$-Test ${ }^{b}$ Fisher's exact test; ${ }^{*}$ Mann-Whitney; ${ }^{a}$ Pearson Chi-Square; ${ }^{b}$ Fisher's exact test; ${ }^{c}$ Kruskal-Wallis Test

Table 2 Comparison of TIMI Flow between Streptokinase and Alteplase

\begin{tabular}{|c|c|c|c|c|}
\hline \multirow{2}{*}{$\begin{array}{l}\text { TIMI } \\
\text { flow } \\
(\mathrm{n}, \%)\end{array}$} & \multicolumn{2}{|c|}{ Fibrinolytic } & \multirow[b]{2}{*}{$\begin{array}{l}\text { Total } \\
(\mathrm{n}=54)\end{array}$} & \multirow[b]{2}{*}{$p$-value } \\
\hline & $\begin{array}{l}\text { SK } \\
(n=27)\end{array}$ & $\begin{array}{l}\text { tPA } \\
(n=27)\end{array}$ & & \\
\hline 2 & $9(33,3)$ & $11(40,7)$ & $20(37)$ & \multirow{2}{*}{0,573} \\
\hline 3 & $18(66,7)$ & $16(59,3)$ & $34(63)$ & \\
\hline
\end{tabular}

\section{Discussion}

From the baseline characteristics found that men were most often found in STEMI, with a total of 48 people ( $88.9 \%$ ). Previous research says that the number of STEMI events is more common in man as much as 3-4 times compared with the woman [3], [4]. The average age was 54 years old, with the lowest age range 46 years old, and the highest age of 62 years old. An increasing in age risk factor, the incidence of cardiovascular disease also increases [4].

This study was divided into two major groups, anterior and inferior STEMI. Where overall anterior STEMI was greater than inferior. The results of this study are consistent with those of Kennedy et al. (1979), anterior STEMI is more common when compared with inferior STEMI [5]. The results showed that STEMI patients came with an average of 3 to 6 hours of onset, with a total of 25 patients (46.3\%), of which 11 were fibrinolytic with SK and 14 with tPA, with median 4 hours, the onset range of 0.5 hours to 11.5 hours. Then followed by an onset of fewer than 3 hours, amounting to 21 patients (38.9\%), with 12 patients performed fibrinolytic with SK and 
nine other patients with TPA. Compared with previous studies, where the high-fibrinolytic efficacy of onset $<6$ hours, and fibrinolytic action with onset $<3$ hours, the results given almost the same as the pPCI [4].

The results of laboratory tests are significant, i.e. MPV, Troponin and CKMB. The average value of MPV from 2 large groups of fibrinolytic equal to $9.77 \mathrm{fL}$ (p-value $=0.044$ ). From this results it can be concluded that the initial value of MPV is low, the fibrinolytic success rate is higher. MPV describes platelet function, the study of Bath et al. (1996), assessed that high MPV was more aggressive in responding to platelet aggregation, resulting in lower MPV values, decreased platelet adhesion, resulting in increased fibrinolytic success [6], [7].

Another assessment of laboratory tests that was statistically significant was troponin levels. In this study troponin assessment was only based on the presence or absence of Troponin, due to the examination of different type of troponin, Troponin $\mathrm{T}$ and Troponin I. From this study it was found that the levels of Troponin (-) were higher than the troponin (+), 30 patients $(55,6 \%)$ with 24 patients $(44.4 \%)$ with $\mathrm{p}=0,000$. The results are consistent with the onset of chest pain $<6$ hours, with the median onset of chest pain that is 4 hours. Levels of troponin in STEMI patients increased in peripheral blood 3-4 hours of onset of infarction and persisted for up to 2 weeks [4].

The total 54 samples, 34 patients (63\%) were obtained with TIMI flow 3, of which 18 were using SK and 16 with TPA. The results were slightly different from the previous research done by de Lemos et al. (2001), which compared the TIMI flow between the administration of TPA and SK in the TIMI-14 and HIT-4 studies. From these two studies mentioned that TIMI flow 2 and three more in the group TPA, whereas in this study TIMI flow three more on giving SK. The difference of this study with previous, possibly due to anticoagulant before coronary angiography action, thus affecting TIMI flow at the time of coronary angiography. The p-value obtained is 0.573 , meaning that there is no difference of TIMI flow between giving of SK and TPA [2]. TIMI flow assessment is subjective, to assess the magnitude of the difference between the two observers the Kappa test was used to see the difference between the observed agreement. From this research got a value of Kappa (K) 0,623, it means a good inter-observer agreement [8].

\section{Conclusion}

From this study, we can conclude that there is no difference of TIMI flow between SK and TPA on STEMI patients after successful fibrinolytic therapy.

\section{REFERENCES}

[1] J. L. Mega and D. A. Morrow, "ST-elevation myocardial infarction: management," Mann D, Zipes D, Libby P, Bonow R. Braunwald's heart disease: a textbook of cardiovascular medicine. 10th ed. Philadelphia: Elsevier, pp. 1095-1147, 2015. 
[2] J. A. de Lemos and E. Braunwald, "ST segment resolution as a tool for assessing the efficacy of reperfusion therapy," Journal of the American College of Cardiology, vol. 38, no. 5, pp. 1283-1294, 2001.

[3] EUGenMed et al., "Gender in cardiovascular diseases: impact on clinical manifestations, management, and outcomes," European heart journal, vol. 37, no. 1, pp. 24-34, 2015.

[4] B. Ibánez et al., "2017 ESC Guidelines for the management of acute myocardial infarction in patients presenting with ST-segment elevation.," Revista espanola de cardiologia (English ed.), vol. 70, no. 12, p. 1082, 2017.

[5] H. L. Kennedy, R. J. Goldberg, M. Szklo, and J. A. Tonascia, "The prognosis of anterior myocardial infarction revisited: A community-wide study," Clinical cardiology, vol. 2, no. 6, pp. 455-460, 1979.

[6] P. M. Bath and R. J. Butterworth, "Platelet size: measurement, physiology and vascular disease.," Blood coagulation \& fibrinolysis: an international journal in haemostasis and thrombosis, vol. 7, no. 2, pp. 157-161, 1996.

[7] D. S. R and D. Ganesamoorthy, “"Relationship Of Platelet Distribution Width And White Blood Cell Count On Admission With St-Segment Resolution In Patients With St-Elevtion Myocardial Infarction Thrombolysed With Streptokinase," IOSR Journal of Dental and Medical Sciences, vol. 15, no. 08, pp. 147-172, Aug. 2016.

[8] B. Murti, Struktur Riset, Matrikulasi Program Studi Doktoral, Fakultas Kedokteran UNS. Surakarta, 2011. 